\title{
Teaching mathematics from the perspective of Mathematics as a discourse
}

\author{
Ensino de matemática na perspectiva da matemática \\ como um discurso
}

Ronaldo Barros Ripardo ${ }^{1}$

\begin{abstract}
The discussion presented in this article is based on the theoretical principles of Sfard in considering Mathematics a discourse, characterized by the use of words, visual mediators, endorsed narratives and routines. Endorsed narratives are taken as a similar category to Marcuschi's discussion with regard to the text, assumed to be - roughly - a sociodiscursive realization through text genres. Thus, the objective of this text is to discuss the teaching of mathematical discourse in light of the theoretical assumptions of textual linguistics for teaching text genres. Based on the didactic sequence model proposed by Dolz, Noverraz and Schneuwly, this study presents a general architecture as a proposal for a didactic sequence for teaching school mathematical discourse to develop an exploration routine, understood as an action that leads to the production of a mathematical fact/theory.
\end{abstract}

Keywords: Mathematical discourse. Text genres. Didactic sequences. Discourse.

Resumo: A discussão tecida neste artigo parte do pressuposto teórico de Sfard em considerar a matemática como um discurso, que se caracteriza pelo uso de palavras, mediadores visuais, narrativas endossadas e rotinas. Narrativas endossadas são tomadas como uma categoria similar à discussão de Marcuschi no que concerne ao texto, considerado, grosso modo, como uma realização sociodiscursiva por meio de gêneros de texto. Assim, o objetivo deste texto é discutir o ensino do discurso matemático a luz dos pressupostos teóricos da linguística textual para o ensino de gêneros de texto. Tomando por base o modelo de sequência didática proposto por Dolz, Noverraz e Schneuwly, apresenta-se uma arquitetura geral como proposta de sequência didática para o ensino do discurso matemático escolar tendo como perspectiva o desenvolvimento de uma rotina de exploração, entendida como uma ação que leva à produção de um fato/teoria matemática.

Palavras-chave: Discurso matemático. Gêneros textuais. Sequências didáticas. Discurso.

\footnotetext{
${ }^{1}$ Universidade Federal do Sul e Sudeste do Pará (UNIFESSPA), Instituto de Ciências Exatas, Marabá, PA, Brasil. E-mail: <ripardo@unifesspa.edu.br>.
} 


\section{Introduction}

The discussion presented in this article shares the idea that mathematics is a human creation guided by social and cultural conditions, among others. From this design derives - as a theoretical model - the proposition of Sfard (2008), according to which mathematics is a discourse. For that author, mathematics understood as a discourse emerges from the need for communication. It is in social interactions that mathematical discourse materializes. The objects of this discourse are not tangible; they are discursive constructions born within discourse itself rather than an external reality. In fact, talking about the object and the object itself are both object and discourse. This makes mathematics one self-sustained discourse, especially in the form of written texts.

One of the features of mathematical discourse, from the perspective of Sfard (2008), is the production of endorsable narratives, which can also be understood as a concept close to that of text genres (TG) according to the theoretical propositions of Marcuschi (2008). To Marcuschi, TG are social forms - more or less stable - of communication production that materialize the text; they are sociodiscursive productions.

Starting from the adoption of the concept that mathematics is a discourse that produces its own TG, comes the proposition that such texts should be part of what is taught in math. Thus, the textual linguistics discussions that drive the teaching of TG to language teaching come in handy, especially the model of didactic sequences proposed by Dolz, Noverraz and Schneuwly (2004).

Therefore, this article, which is part of the theoretical framework of a doctoral research (RIPARDO, 2014), aims to discuss the teaching of mathematical discourse in light of theoretical principles of text linguistics for teaching TG, since, according to Sfard (2008), communicative competence is the fundamental element to think about mathematics learning.

\section{Mathematics as a discourse}

To Sfard (2008), thought is communication. Although thinking is an individual activity, Sfard (2008) considers that it develops through collective activities. Interpersonal communication is the process of individualization by which social activity is transformed into thinking. Human thought may be understood as a special form of communication activity, which takes place with oneself.

The bases upon which the assumptions of this position are based are Vygotsky's sociodiscursive interactionism, and Wittgenstein's language games. Such theories converge as they consider language learning to be a result of social activity. The former, a follower of Marxist philosophy, defends that it is in social interactions and through them that language acquisition and knowledge production occur. The latter considers that language is connected to different forms of life and to the practices therein developed, in specific contexts and in an interpersonal praxis.

To Sfard (2008) learning is commognitional. Such word is the combination of communication and cognition. To commognitional learning, forms of thinking and knowledge acquisition are achieved through the search for communication. From this perspective, communication cannot be seen solely as a tool to help thought. Rather, the fundamental thesis of 
the communicational approach to cognition is that human learning is nothing but a special type of social interaction set out to modify other forms of social interaction. More than identify someone's properties that spur changes in their behavior, it is necessary to pay attention to the interactions where these changes in behavior take place (SFARD, 2008).

To Sfard (2008), responses given in interactions derive from argumentations resulting from questions people ask themselves and the information they obtain. Therefore, thinking takes place through and in a dialogic process. The answers sought are obtained internally, however, the nature of the needs from which they arise is of interpersonal nature. The activities in which humans participate daily and the needs arising from them are immersed in practices that call for different types of communication. Thus, the knowledge that is produced can be viewed as a discourse since it is a product of social interactions. Therefore, in a broader definition by the author, discourse is a special type of distinguished communication based on one's repertoire of admissible actions and the way these actions are coupled with (re)actions. Roughly speaking, social interaction is to act in face of a discourse charged with the potential to produce knowledge.

According to Sfard (2008), mathematical discourse may be considered an autopoietic system, especially when crystalized in the form of a written text. The objects of this system are structured into several levels, which are discursive constructions themselves and constitute part of the discourse, because they are intangible objects. Both the objects and talking about them emerge from the layers of discourse and build new discursive strata of the system.

As a discourse, which is realized through communication in interaction, it would probably be impossible to define if a given object can be characterized as being part of the mathematical discourse based on a single characteristic common to every category of objects of this discourse. The analysis relying on four properties of one discourse can be important in the process of deciding if a given realization can be accounted for as an example of mathematical discourse or another type of discourse. The said properties are: word use, visual mediators, endorsed narratives and routines (SFARD, 2008).

Words allow saying something about the object. The grammatical categories for name, for example, show a peculiarity of the mathematical knowledge. The noun triangle identifies knowledge while distinguishes it from others: the words 'triangle' and 'derivative' do not refer to the same object within mathematical discourse.

Visual mediators are objects used to communicate. In mathematical discourse, images derive more from symbolic artifacts than from material objects existing independently from speech. Among other purposes, written symbols help organize and set up mathematical discourse during interaction. As an example, we can mention the algebraic notation (xy, $\equiv$ ), arithmetic operators $(+, \div,\{\}, \Pi, \sqrt{ }, \leq, \neq,=)$, geometric notation $(\Delta \mathrm{ag} b,\llcorner)$, set notation $(\cap$, $\varnothing)$; numerals $(2, \mathrm{dxxv}, 3 / 80,(33) \overline{)})$; calculus notation $\left(\Sigma, \int, \mathrm{dx}, \pm, \infty\right)$; logical operators $(\leftrightarrow, \rightarrow$, $\mathrm{v}, \sim)$, among others.

Routines are to be understood as the recurrent actions in which participants mobilize words and visual mediators to structure textual sequences, that is, narratives, according to their discursive needs. Mathematical routines are typical problem-solving tasks such as to define, conjecture, estimate, calculate, demonstrate, etc.

Endorsed narratives are ordered sequences of verbal expressions. Roughly speaking, they are the texts that describe objects, relationships between objects, and processes through which such objects are constructed, subject to approval or refutation by the community that 
practices this very discourse. The process of endorsement is a purely deductive relation between narratives, in case the discourse is practiced by professional mathematicians, and is impervious to any external consideration. Some examples of endorsed narratives are theorems, definitions, axioms, etc. One narrative may have several functions, such as defining an object, depending on the use required by the routine to which it is associated.

Words and visual mediators as tools; routines as processes; and endorsed narratives as results, embody the mathematical discourse. However, tools are not used without criteria nor can processes be conducted in absentia of mathematists ${ }^{2}$. The narratives produced to be endorsable and, therefore, become validated results, should be erected under well-defined rules. These both regulate the participation of interlocutors and ensure the self-production of discourse.

Performing an action in a discourse means understanding which rules regulate the interlocutors' modes of participation. Knowing what to say and what not to say, when to talk and when not to talk, to proceed or not with a conversation, to agree or disagree with the interlocutor etc., are imitation activities compared to previously performed processes whose parameters are internalized as a certain set of principles that will allow future behaviors to be performed in a non-arbitrary way.

Thus, in relation to the mathematical discourse, Sfard (2008) distinguishes between two specific sets of rules: object-level rules and metadiscursive rules, also called metarules.

Object-level rules "are narratives about regularities in the behavior of objects of the discourse" (SFARD 2008, p. 201). So to speak, mathematical discourse texts, made up of words and visual mediators, count as the rules that characterize mathematical objects and, concomitantly, are included as part of the list of objects of that discourse since they derive from a specific routine validating them; this results in a self-generative nature. When said that "a whole number $\mathrm{p}$ is a prime number and when $\mathrm{p} \neq 0,1-1$ and $\mathrm{D}(\mathrm{p})=\{1,-1, \mathrm{p}, \mathrm{p}\}$ ", it can be said that this narrative has been endorsed by the community of mathematicians, that the object 'prime numbers' was added to the mathematical discourse, and that it has now become a rule: a prime number, the mathematical object, in the set of integers, cannot be another number that exceeds the limits imposed by this narrative.

It is likely that, for the narrative about prime numbers to be endorsable, it was necessary to be based on the premise - present on the number theory discursive layer - that the set of integers has a subset formed by numbers that are divisible by only two couples of numbers - the number itself, 1, and their respective negatives - and another subset that can be divisible by more than these two pairs of numbers. Therefore, the convenience in distinguishing between these two subsets by different names leads to defining one as prime numbers and the other as composite numbers, in such a way that, before a whole number, for example, it is possible to tell whether it is a prime.

\footnotetext{
${ }^{2}$ Sfard (2008) distinguished a mathematist from a mathematician; the first term is to name any person practicing the mathematical discourse while the latter is for those who practice mathematics as a profession.
} 
The narrative about prime numbers is a consequence of one of the actions frequently identified in the activity of mathematicians when, by convention, they formulate and endorse narratives to characterize a mathematical discourse object and, at the same time, tell them from others. For this reason, narrative is distinctive, clear, precise and needs no demonstration. Such situation indicates "patterns in the activity of the discursants trying to produce or substantiate object-level narratives" (SFARD, 2008, p. 201). Whenever a standardized activity, such as this, is detected, meta-discursive rules are present.

The level of meta-rules is higher than that of object-level rules. While the first concerns what interlocutors do when they manipulate and/or produce new objects, the second concerns the behavior of objects and/or distinguishing one object from another in the mathematical discourse. A reasonable interpretation for this difference in levels may be that metarules are related to processes while object-level rules are related to products. It is to be admitted that studying discursive products is far less complex than studying the processes that created them (SFARD, 2008).

As complex - but also dynamic - processes, instead of rigid and closed structures, metarules must be viewed with its five endogenous characteristics (SFARD, 2008). They have variability: historical developments, for example; implicitness: interpretative nature of mathematists intrinsic to the act of explaining metarules; normativity: rules that are actually followed by speakers in a given community; flexibility: the meta-discursive rules indicate what is allowed and what cannot be accepted in a mathematical discourse routine, but not what interlocutors should do in practice; contingency: what counts as right and unquestionable today is the result of the development and gradual adaptation of mathematical communication, eliminating what does not work and setting up what meets the objectives of the discourse.

\section{Routines and narratives in mathematical discourse}

To Sfard (2008), the major objective of mathematical discourse routines is to produce narratives on mathematical objects. Such routines may be of three types: explorations, deeds and rituals.

A routine counts as exploration if its outcome is the production of a narrative, a closing condition, on the endorsable mathematical objects by people who have some authority in the community to which the routine belongs. That is, it culminates in a theoretical construction proposed through a narrative endorsed by the community of specialists. Deeds are a second type of routine; their primary aim is a deed or change in the physical state of the object more than producing narratives. As an example, picture a person manipulating pieces of straw of different sizes to form a triangle. If they worry more about finding out which pieces form the triangle than setting up a logical relation between the length measures of the segments - represented by the straws - to form the figure, free from a narrative that limits this relationship, then this is a deed routine. A third type of narrative are rituals. Sfard (2008) argues that in many discursive situations, interlocutors are not concerned with closing the routine, that is, with producing a narrative or physically manipulating the object. It seems that creating and keeping a liaison with other people, as to recognize that they are an authority in that discourse, would top the list of interests of interlocutors, at least, of some of them. 
Producing routines and endorsable narratives is not an exclusive privilege of mathematical discourse. Other discourses also have their own ways to develop and/or improve their discursive objects and validate their narratives, erected by them and about them. To Sfard (2008), what substantially differentiates the mathematical discourse from others is its self-generative nature, characterized by the purely deductive relationship between narratives.

Among the three types of mathematical discourse routines, the only ones that do not count as a complete performance, in the sense of being a produced object, are rituals. Both deeds and explorations are concerned about the closing conditions. However, only in exploration does the closing of the performance culminate in the production of a narrative to be endorsed, whereas the primary concern of deeds is the physical transformation of the object as a closing condition. Therefore, it should be considered that a narrative cannot be taken without considering the routine that produced it.

Explorations are routines that genuinely produce narratives. A narrative is " [...] any sequence of utterances framed as a description of objects, of relations between objects, or of processes with or by objects" (SFARD, 2008, p. 223). Exploration routines can be used on different layers of the mathematical discourse. However, the criteria used to validate the produced narratives may not always be the same. In colloquial situations, empirical evidence is commonly used as endorsement criteria, while in academic settings the use of other narratives is the backbone of the process to substantiate narratives (SFARD, 2008).

Endorsing narratives is the process by which interlocutors evaluate if the text produced as a result of exploration does not go against metarules applied in the implementation of the routine. Endorsement is dependent, to a greater or lesser degree, on the knowledge that those involved in the discursive act have about the discourse rules. After all, to acknowledge the success of a performed action, the specialist must take possession of it and evaluate it as if they were the author, reconstructing the steps that led to the production of the mathematical fact. This becomes impossible without mastering the rules of mathematical discourse. If this does not occur, using other rules - not always validated - could be an alternative. In any case, endorsement happens only if the narrative validation criteria are clear and all agreed by those involved.

Explorations and narratives, to some extent, are like the sides of a coin. A narrative cannot be separated from the routine that produced it, nor can a routine be separated from the narrative that closed the discursive act. In other words, it makes no sense to talk about process without mentioning the product, and vice versa. Sfard (2008) classifies the exploratory routines into three types, based on the relationship between the routine and the produced narrative: construction, substantiation and recall.

Construction of narratives is the process by which narratives are made by a person about a discursive discovery, observation, reflection etc. The process leading to this construction can take place through a direct realization, when the narrative comes from an immediate and instant relationship made by a mathematist with no mediation of other discursive artifacts, and the narrative generally follows the direct visualization of perceptible objects by sight. Mathematicians, however, construct new narratives from previously-endorsed narratives. It is a process gradually built into layers. As a narrative is endorsed, it becomes a step for others to be built. More and more strata of the mathematical discourse are built, thus increasing the number and complexity of the mathematical theories. 
To substantiate or endorse narratives, according to Sfard (2008 p. 231), “[...] is a process through which mathematists become convinced that the narrative can be endorsed." Endorsement can be done in endless and equally-complex ways. For the mathematician, a narrative is endorsed if it meets regulatory criteria of the academic discourse in its various instances. Sfard (2008) states that a substantiation with this profile allows including the narrative as part of a theory, i.e., it is available for mathematicization.

Recall is the third way by which the interlocutor can reach a narrative at the end of an exploratory performance. It results from the fact that exploration resorts to other endorsed narratives and recalling them is crucial to the fluency of a person within the discourse (SFARD 2008). However, Sfard (2008) points out that recalling previously-endorsed narratives can be done immediately, while in other cases they may need to be reconstructed. In addition, "the way one tries to recall endorsed narratives is, no doubt, revealing. It can indicate a lot not just about how the narratives were memorized, but also about how they were constructed and substantiated originally." (SFARD, 2008, p. 236).

When it comes to learning mathematics, Sfard (2008) considers that it takes place as a process of individualizing mathematical discourses. It means to become capable of establishing a mathematical communication with oneself as well as with other people, and it involves passing from one unobjectified discourse, that is, a personal discourse, in which the interlocutor talks about actions taken onto the object, to an objectified, impersonal discourse, in which the interlocutor talks about the relations with the object. To the author, learning a new discourse must be stimulated by the urgent need to communicate, since, to communicate, subjects need to compromise their discursive forms. The gap between these two types of discourse is directly related to the way students develop a routine, if they perform it as a deed, ritual or exploration. The latter is typical when a discourse is or is becoming objectified.

\section{Text genres}

Discourse, text, and text genre are important categories in Marcuschi's (2008) discussions and the boundaries between these categories are not rigid, well-defined or easily noticeable.

For the author, the discourse is related to the plan of enunciation, the enunciation functioning and the overlapped effects of sense in its sociointeractive circulation. Discourse would be something like a set of statements deriving from the same discursive formation, a complex practice.

Marcuschi (2008) understands that texts are the observable empirical material to which one has direct access. They are linguistic units that perform a communicative function in a social context. That is, in an enunciative situation there are endless possibilities to perform it through texts, leaving the producer with the choice of a genre that will materialize it. As an empirical linguistic phenomenon, which is observable, the text presents "[...] all configurational elements that give access to other aspects of the analysis" (MARCUSCHI, 2008, p. 84, our translation). It is inferred, therefore, that the text is what you can actually see, the artifact that materializes discursive actions and grants access to other aspects of enunciation.

Text genre can be said to be a social and social-discursive practice (MARCUSCHI, 2008). Various social practices result in some artifact. Constructing buildings is a social form 
of activity of a civil engineer, and a building is a material object arising from that practice. While the work of an engineer is situated in the field of construction, TG is a social practice within discourse and communication.

The TG is situated between discourse and text, as a bridge that connects these two categories; this is why it is said to be a textual-discursive practice. The text is the figure object, the observable language configuration whose texture grants access to aspects of discourse. Such a text configuration or its observable aspects are determined by genre. This comes at a time of planning, consciously or not, that precedes the production itself, i.e., in enunciation management. This layout is coordinated by well-established cultural aspects and clear objectives, which, along with the genre profile, gives the text its final physical - observable configuration. Depending on the genre, some rules or standards are more or less explicit and determine what may or may not be done in the text, what is permissible and what is not to be tolerated (MARCUSCHI, 2008).

The thesis of Marcuschi $(2008,2010)$ is that verbal communication is only possible due to the realization of texts and its existence would be impossible without the mediation of the genre. Thus, sociointeractive studies of linguistic production are centered in TG. According to Bronckart (2009 apud MARCUSCHI, 2008, p. 103), the appropriation of TG is an important way to socialize and to be part of human communicative activities. This view leads Marcuschi $(2008,2010)$ to see TG as forms of discursive legitimacy.

In summary, genre materializes text in recurrent communicative situations. According to Marcuschi (2008), TG are texts found in the most diverse daily events. As a product of integration of historical, institutional, social and technical forces, they have specific sociocommunicative standards given by functional compositions, enunciation goals and styles. They are written or oral text forms, situated historically and socially, which arise within discursive fields.

The discursive domain is linked to the discursive production instances or human activity where TG originate and circulate. The various human activities characteristic of a specific discursive instance end up producing institutionalized communicative routines that deploy power and take the form of genres. These are not texts or discourses but provide the appearance of many of them, since the TG are institutionally marked (MARCUSCHI, 2008, 2010).

To Marcuschi (2008), once the student arrives at school communicating effectively, the role of the school is to create possibilities for improving the development of this communicative competence. To do so, schools must focus their efforts on working with oral and written forms, expanding the language use repertoire, which is not always enabled by the daily life outside the school. Another action is to prioritize reflexive - rather than normative - teaching, by adopting as communicative competence a more global posture on the ethnography of speech, which involves analysis of verbal interactions and discursive productions, in addition to verbal and communicative activities, without losing sight of cognition.

One way of working with TG proposed by Dolz, Noverraz and Schneuwly (2004, p. 82) uses didactic sequences, understood as a "set of organized school activities, in a systematic way, around an oral or written TG". These authors consider genres as the instrument to act discursively.

For Dolz, Noverraz and Schneuwly (2004), the discourse act is done by means of texts that differ from one another for they are produced under different circumstances. However, despite this, there are regularities that are present and that facilitate communication. For 
teaching school TG - those that are designed to help students improve their proficiency in usually unfamiliar communication contexts -, the didactic sequences allow students to access new - non-quotidian - language practices for them.

In essence, the character of this methodology for the teaching of genres is modular and is guided by the creation of text production conditions similar to a real communication context, a need to act discursively that goes beyond the mere urgency of a school activity. The diagram below (Figure 1) illustrates these authors' proposal for the teaching of genres.

Figure 1. Organization of didactic sequences

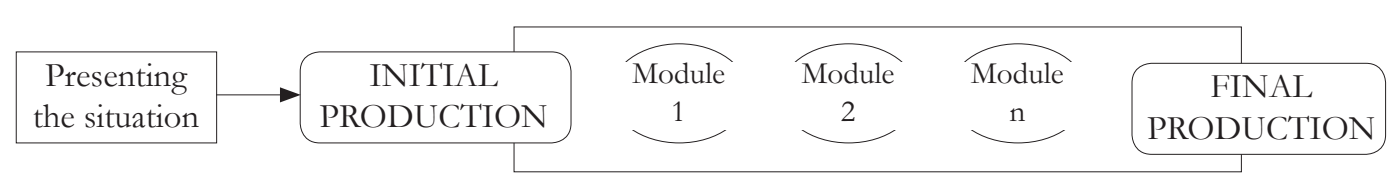

Source: Dolz, Noverraz and Schneuwly (2004, p. 83).

The presentation of the situation consists of the moment when the task is formulated to be developed by the students. This stage includes the choice of genres, the interlocutors and the form of broadcasting - television, newspaper, paper etc. It also includes choosing the content or theme that these productions will address. In short, this will be the first time students meet the genres, which will culminate in the initial production. It may be individual or collective and involves an assessment by the teacher. This is a general outline and students do not have very specific guidelines about the genre they are producing or what communication project will be consolidated in the final production.

The modules consist in rewriting as many times as necessary until production reaches a state that demonstrates that students have learned about the genre, considering the socio-communicative purposes in question. The modules have exercising activities to provide the necessary tools to the new domain, once the problems are dealt with as they arise.

The modular character of the sequence permeates a few steps. The first concerns the work focused on different levels of problems, which involves the representation of the communication situation, planning the content, text planning and producing the text. The second is focused on the variation of activities and exercises, involving monitoring tasks and text analysis, simplified tasks of text production and the development of a common language. The third highlights the capitalization of genre-related acquisitions, which means an ability to talk about genre using a technical language that is common to both the class and the teacher.

The final production will be the moment when students will complete the writing of the genre, reflecting on what they have done for the text to have reached its current state. Students will have control over what they did, why they did it and how they did it. In other words, it is a reflection that aims to make them learn how to regulate their actions and text production forms. 
Dolz, Noverraz and Schneuwly (2004, p. 95) emphasize, among other important aspects, that working in this methodology involves the notion that the text is a temporary object subject to a rewriting process and the "student should learn that writing is (also) rewriting". Another detail is the use of reference texts, which, in short, is the opportunity to familiarize with other stable texts and with the language of others, which allows for criticism.

\section{School mathematical discourse}

Discourse, the backdrop of Sfard's theory combines the notion of discourse proposed by Marcuschi with the fact of considering that language use in communicative activities is done in dialogue in a more-or-less standardized form, determined by issues of collective nature, usually under institutional coercions.

Discourses are produced in the most diverse spheres of human activity, which come close together due to erecting and organizing similar forms of communication in which people are more likely to participate because they can interact under their precepts. In these discursive instances, called discursive domains by Marcuschi and discursive communities by Sfard, the product of their interactions are oral and written texts that - due to their conditions of social use, and since they historically situated in such instances - acquire certain stability and are validated as legitimized knowledge. These are the endorsed narratives/TG deriving from discursive practices/effective routines, always implanted with power.

Considering mathematics a discursive domain, and without violating its discourse condition from Sfardian perspective, it seems prominent - when dealing with endorsed narratives - to identify the elements associated to TG, discussed by Marcuschi (2008), which interfere in their production (Figure 2).

Figure 2. Analytical categories relating to TG

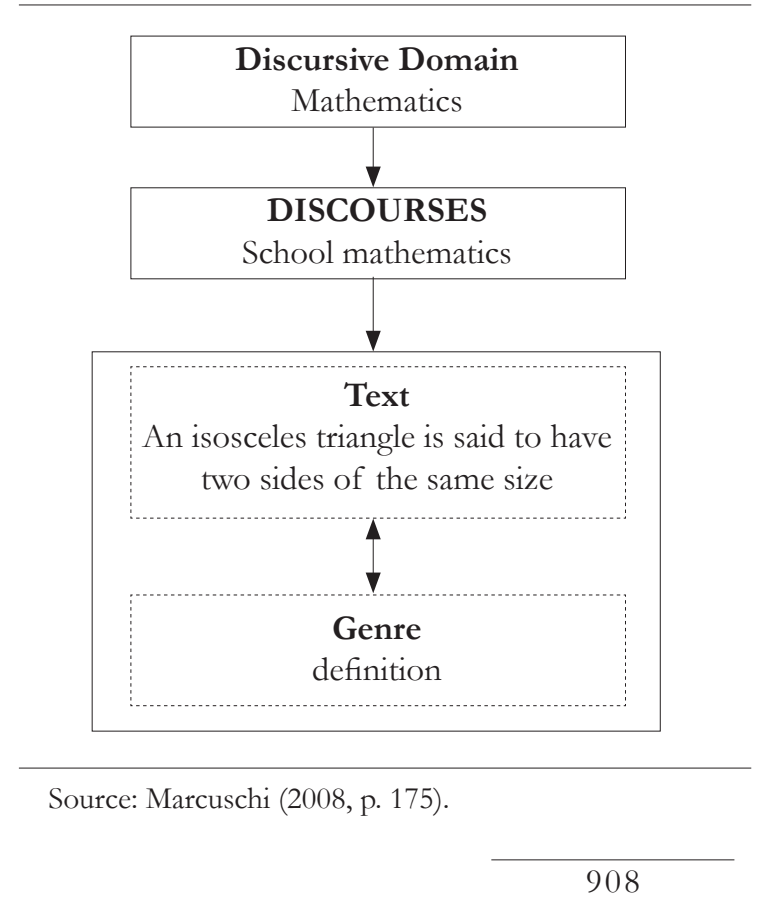

Ciênc. Educ., Bauru, v. 23, n. 4, p. 899-915, 2017 
The mathematical discursive domain comprises the school mathematical discourse. In the routines therein developed, such as defining, it is common to produce and broadcast the TG definition from textbooks used at school.

Mathematics is a discursive domain just like the juridical, religious, journalistic etc., because there are institutional relations at different levels regulating communicative actions determining what may or may not, to some extent, pass the scrutiny of experts in the discourses produced in this domain. Thus, mathematics produces TG which are grouped around a theme for possessing specific linguistic, socio-communicative and functional characteristics, as well as a circulation space and their own supports.

The school mathematical discourse, as one of these discourses produced under the math discursive domain, differs from colloquial and literary mathematical discourses ${ }^{3}$. Colloquial discourse is influenced by several other domains and elements whose contours are difficult to define, given the unique context of each person's daily life. Roughly speaking, one can say that the routines of this discourse are more informal and have to do with solving problems that emerge from the everyday practices, often linked to the work sphere. According to Sfard (2008), the narratives produced in this discourse are eminently oral, validated by the recurrence of empirical objects or artifacts. The literary discourse is related to the space of the academies and scientific institutions whose routines are conducted under the precepts of science. The objects produced in this discourse are written narratives endorsed by specialists through deductive processes among other narratives. The school discourse is a product - above all - of these two discourses, although its nature goes far beyond a view that the former is an intermediary between the latter.

School mathematical discourse involves a mix of routines and narratives produced in the colloquial and literary mathematical discourses, as well as those of other domains, such as the pedagogical, sociological, political etc. The pedagogical and psychological discourses, as well as others, are fed with scientific and institutionalized theories of a more general character about teaching and learning, which influence teacher formation. The political discourse, in turn, imposes its legislations, financing, goals etc. Based on these complex relations, TG are produced, such as definitions, theorems etc., which are typical of the literary mathematical discourse - but which circulate in schools, especially in school books - with genuine characteristics and specificities in the validation rules in the classroom.

The scope of activities in school mathematical discourse comprises the presence of several TG. The Chart 1 illustrates some of them.

Such TG or endorsed narratives presented are an object of learning in terms of production written by the student and must be associated with a routine, usually an exploration, for

\footnotetext{
${ }^{3}$ It is not possible to define how many discourses are produced under the mathematics discursive domain. Thus, the day-by-day - school and literary - mathematical discourses are some of them and they should not be treated as if they were part of an exhaustive list. Moreover, even the names "literary" and "quotidian" or "colloquial" must be viewed with some caution, for the limits between them may not be so clear, depending on the aspects taken into consideration in the analysis.
} 
even though deeds also include the production of endorsable narratives - in a secondary way -, it is in exploitations that narratives have their potential role, since they can be used to construct new narratives, they can substantiate other narratives, or they can be recalled. It is impossible to say that TG are linked to the nature of each routine, because sometimes a routine functions as exploration to one student, i.e., it culminates in the production of a mathematical object expressed in narrative form, but it is a deed to another student or even a ritual. However, it is possible to relate some routines to the production of some TG, as well as their characteristics to the routines where they were handled.

Chart 1. Some TG school mathematical discourse

\begin{tabular}{|c|c|c|c|c|}
\hline Genre & $\begin{array}{l}\text { Structural } \\
\text { form }\end{array}$ & $\begin{array}{c}\text { Communicative } \\
\text { purpose }\end{array}$ & Content & Text example \\
\hline Definition & $\begin{array}{l}\text { Name of } \\
\text { the object, } \\
\text { description } \\
\text { and } \\
\text { example. }\end{array}$ & $\begin{array}{l}\text { To characterize } \\
\text { an object or } \\
\text { mathematical } \\
\text { situation by a } \\
\text { name. }\end{array}$ & $\begin{array}{l}\text { Objects and } \\
\text { mathematical } \\
\text { situations. }\end{array}$ & $\begin{array}{l}\text { When we want to represent a bracelet, a } \\
\text { picture frame or the structure of a roof, } \\
\text { we draw figures such as these: } \\
\text { These geometric figures have special } \\
\text { names: circle, rectangle and triangle } \\
\text { and are called two-dimensional (or flat) } \\
\text { (ROGERI, 2006, p. } 85 . \text {.). }\end{array}$ \\
\hline Theorem & $\begin{array}{l}\text { Subject } \\
\text { name, } \\
\text { premise } \\
\text { and thesis } \\
\text { (conclusion). }\end{array}$ & $\begin{array}{l}\text { Raise the } \\
\text { demonstration or } \\
\text { the result of it. }\end{array}$ & $\begin{array}{l}\text { Mathematical } \\
\text { objects }\end{array}$ & $\begin{array}{l}\text { Another important metric property of } \\
\text { triangles is that whatever triangle you } \\
\text { consider the sum of its inner angles is } \\
\text { always the same: } 180 \text { degrees (ROGERI, } \\
2006, \text { p. } 85 \text { ). }\end{array}$ \\
\hline Proof & $\begin{array}{l}\text { Arguments, } \\
\text { evidence } \\
\text { and } \\
\text { conclusion. }\end{array}$ & $\begin{array}{l}\text { Check the } \\
\text { consistency of } \\
\text { a conclusion or } \\
\text { reply. }\end{array}$ & $\begin{array}{l}\text { Mathematical } \\
\text { objects and } \\
\text { situations. }\end{array}$ & $\begin{array}{l}\text { If you add the income of the } 1^{\text {st }} \\
\text { fortnight and the income of the } 2^{\text {nd }} \\
\text { fortnight, you get how much this } \\
\text { restaurant owner earned in a month. By } \\
\text { adding up the expenses on suppliers, } \\
\text { rent, payroll and social security } \\
\text { contributions, taxes and accountant, } \\
\text { you get the expenses of this restaurant } \\
\text { owner in one month. By analyzing how } \\
\text { much was earned and how much was } \\
\text { paid you must have realized that there } \\
\text { was a positive balance of R } \$ 400.00 \\
\text { (RODRIGUES, 2006, p. } 72 \text { ). }\end{array}$ \\
\hline $\begin{array}{l}\text { Demons- } \\
\text { tration }\end{array}$ & $\begin{array}{l}\text { Hypothesis, } \\
\text { assumptions, } \\
\text { evidence } \\
\text { and thesis } \\
\text { (conclusion). }\end{array}$ & $\begin{array}{l}\text { To prove or } \\
\text { disprove a } \\
\text { conjecture } \\
\text { through logical } \\
\text { tools. }\end{array}$ & $\begin{array}{l}\text { Mathematical } \\
\text { objects. }\end{array}$ & $\begin{array}{l}\text { QUESTION: } \\
\text { Are the ratios } \frac{a}{b} \text { and } \frac{c}{d} \text { equal? In other } \\
\text { words, can we write the ratio } \frac{a}{b}=\frac{c}{d} \text { ? } \\
\text { REPLY the ratios } \frac{a}{b} \text { and } \frac{c}{d} \text { are equal if } \\
\text { the products } a . d \text { and } b . c \text { are equal. That } \\
\text { is, } \frac{a}{b}=\frac{c}{d} \text { if } a \cdot d=b . c \text { (PIETROPAOLO, } \\
2006, \text { p. } 137 \text { ). }\end{array}$ \\
\hline
\end{tabular}


Chart 1. continuation

\begin{tabular}{|c|l|l|l|l|}
\hline Genre & $\begin{array}{l}\text { Structural } \\
\text { form }\end{array}$ & $\begin{array}{l}\text { Communicative } \\
\text { purpose }\end{array}$ & \multicolumn{1}{c|}{ Content } & \multicolumn{1}{|c|}{ Text example } \\
\hline $\begin{array}{l}\text { Problem } \\
\text { situation }\end{array}$ & $\begin{array}{l}\text { A context } \\
\text { information } \\
\text { data and a } \\
\text { question. }\end{array}$ & $\begin{array}{l}\text { Instigating } \\
\text { the search for } \\
\text { solution to a } \\
\text { mathematical } \\
\text { problem } \\
\text { situation. }\end{array}$ & $\begin{array}{l}\text { Mathematical } \\
\text { or quotidian } \\
\text { topics, } \\
\text { or issues } \\
\text { of other } \\
\text { knowledge } \\
\text { areas. }\end{array}$ & $\begin{array}{l}\text { The game of darts } \\
\text { A dartboard has four regions, } \\
\text { as illustrated. The region } \\
\text { enclosed by the innermost circle } \\
\text { scores 11 points and the subsequent } \\
\text { crowns score 7, 3 and 2 points, } \\
\text { respectively. One day, three friends } \\
\text { named André, Carlos and Paula, were } \\
\text { playing and after each of them had } \\
\text { thrown six darts, all had the same score. } \\
\text { You will find out what that score was } \\
\text { and how each one of them got it, from } \\
\text { the following information: } \\
\text { - André was the one who hit more darts } \\
\text { in the central zone. } \\
\text { - Paula was the most regular player, } \\
\text { because she always scored the same } \\
\text { number of points. } \\
\text { - Carlos' darts were spread evenly across } \\
\text { the regions he hit (PIRES, 2006, p. 44). }\end{array}$ \\
\hline
\end{tabular}

Source: prepared by the author.

For the TG problem situation, three characteristics can be noticed. The context information circumscribe a given situation and aim to provide the elements necessary for an initial production of senses for the text, situating the reader about the event in question. The data, which may appear in the form of numbers, designs, figures, schemes etc.; are the mathematical capital to be manipulated through some mathematical discourse rules that will allow reaching a conclusion about the written situation. The problem comes from the relation drawn between contextual elements and the data by means of a fabric that will clear out a question or a request for explanation.

The most usual format of the TG response for a problem situation, deriving from a problem-solving routine, is a setup comprising an interpretation of the situation that generated it, and synthesizes - in general terms - the problem situation information. Next, it is common to present a hypothesis or solution plan that shows a path to be followed in the process of finding an answer to a problem. The proof is all the argumentation process, according to a way of thinking or a set of thoughts, which will solve the question raised in the problem situation. The conclusion comes from the proof and it allows stating something or providing an answer about the situation.

A problem situation can consist of a statement whose validity needs to be proven. In other words, solving this problem situation may consist in the demonstration of a theorem, it may require the routine of demonstrating, and culminate in the TG demonstration. The latter, in turn, may take in other genres, such as definition and axiom. However, the theorem can be a narrative used as a tool to substantiate the proof, with no need for demonstration. 
This dynamism may even take up other nuances depending on the context in which the interaction takes place. Between students and teacher, the validation rules will have one profile and will be used in a very specific way. Among teachers, the endorsement scenario may be very different. For example, between students and teachers, the routine may be that of proving, and not demonstrating, and culminate in the TG proof.

The genres proof and demonstration are relatively close and, at times, they are treated as if they were the same. However, there are perceptible differences between them which concern the routines they generate. The routine of demonstrating involves an entanglement of more formal mathematical theories by means of logical-deductive relations and it is almost always associated to a theorem, deriving from a conditional or implicating mathematical statement. The routine of proving is concerned with showing that one thought employed in a process of problem situation resolution is coherent with the answer obtained. This way of thinking not always employs the most formal properties of the mathematical discourse. This way, the TG demonstration and proof will keep in themselves these marks of routines from which they derived. One of them presents more logical relations between genres while the other argues with the most diverse argumentative linguistic tools.

Considering the present discussion on routines and TG of the school mathematical discourse, it is possible to indicate an important implication concerning the teaching of this discourse. If the mathematical discourse produces TG of its own, so it is coherent to think about the teaching of these genres guided by the assumptions about textual production that are discussed in language teaching. In other words, the recognition of narratives as genres can mean a reordering in the ways they can be worked in Mathematics classes. They can be approached as a text that has linguistic and compositional specificities, among others, and not simply as a rhetorical figure in the context of Mathematics. The domain in the textual production of the TG school mathematical discourse implies the success of the student's performance in exploration and deeds routines, since the production of a narrative is the closing condition of such routines.

\section{School mathematical discourse teaching}

Based on the model of didactic sequence proposed by Dolz, Noverraz and Schneuwly (2004), this study presents a general architecture as a proposal for a didactic sequence for teaching school mathematical discourse to develop an exploration routine.

The foreground of the teaching sequence presented should be what Sfard (2008) calls applicability conditions. Deciding which procedures are adequate or not for a given situation is done based on other experiences whose parameters have been internalized and will be recurrent to identify what would be appropriate for future routines. Even if a routine is familiar to a mathematist, the situations likely to be found in this routine can vary considerably in face of mobilized mathematical knowledge and, therefore, the procedures that can be used may also be multiple. Thus, the function of the first rules used to implement a routine is to indicate to the mathematist which procedures may be appropriate to the situation; it concerns the applicability conditions. Such procedures may be constructed for the first time by the participants of the discourse, usually when the routine is explorations or deeds.

At the end of the performance there is almost always a shared desire by participants for the interlocutor to adhere to the product of the interaction. In other words, the performed act 
must elicit an interpretation of success in relation to the procedure employed, which for Sfard (2008), are rules connected to closing conditions, since they show how to evaluate the end of the performance. This must be, therefore, the background of the didactic sequence (Chart 2).

Chart 2. Architecture of a didactic sequence for teaching school mathematical discourse

\begin{tabular}{|c|c|c|c|}
\hline \multicolumn{2}{|c|}{ FOREGROUND } & \multicolumn{2}{|c|}{ BACKGROUND } \\
\hline \multicolumn{2}{|c|}{ Applicability conditions } & \multicolumn{2}{|c|}{ Closing conditions } \\
\hline $\begin{array}{l}\text { Presentation of } \\
\text { a situation }\end{array}$ & Initial production & Modules & Final production \\
\hline $\begin{array}{l}\text { - Contextualize the } \\
\text { activity plan } \\
\text { - Present the } \\
\text { problem situation }\end{array}$ & $\begin{array}{l}\text { - Present the communication } \\
\text { problem } \\
\text { - Define with the class the } \\
\text { TG to be worked } \\
\text { - Produce an initial written } \\
\text { text according to the routine } \\
\text { (define, demonstrate etc.) }\end{array}$ & $\begin{array}{l}\text { - Global textual plan } \\
\text { - Context of production } \\
\text { of mathematical discourse } \\
\text { - Characteristics of } \\
\text { discourse } \\
\text { - Textual sequence } \\
\text { - Textualization } \\
\text { mechanisms } \\
\text { - Control list }\end{array}$ & $\begin{array}{l}\text { - Endorse the } \\
\text { narrative through } \\
\text { acceptance of } \\
\text { peers }\end{array}$ \\
\hline \multicolumn{3}{|c|}{ Follow up students on routine performance } & \\
\hline & \multicolumn{3}{|c|}{$\begin{array}{l}\text { Exercise strategies/techniques accepted to validate the knowledge/the } \\
\text { narrative }\end{array}$} \\
\hline
\end{tabular}

Source: prepared by the author.

The foreground is directly linked to the presentation of the situation and to the initial production of the proposed sequence for Dolz, Noverraz and Schneuwly (2004). It must provide activities that will lead to the production of an initial text so that rewritings can be planned. Most of the time, in a classroom environment, this text is produced orally, on the conclusions that the student reaches by the end of the first tasks and interactions with peers and the teacher. The teacher is almost always satisfied with this oral production or at most a written version for it - the initial production - without major concerns about its writing according to the specificities of the genre in question. As the mathematical discourse is constructed mainly through the production of narratives that feed the production of other narratives, it is necessary to teach how to produce them, the specificities of the action of producing them, as well as the text that materializes them. Thus, the background involves more specifically the rewriting module and the final production.

In the proposed architecture, in situations where narrative construction routines are proposed, in the foreground, there may be room for activities that challenge students to explore them and make discoveries, such as on the relation between the formation of a triangle through the length measures of the segments that form it. This must lead to an initial knowledge that may be accompanied by narratives, be they more structured or not, about this initial discovery. In the process of rewriting, in the background, this initial knowledge is to be improved as the rewriting modules are worked. Problems in writing what one has to say will also reveal imper- 
fections in the constitution of the mathematical object that were not known or were simply imperceptible to the students. This will create the conditions for students to find out discursive patterns that may be both discoveries about the world and their formation through narratives that create the rules of this discourse. It is a necessary exercise to progressively comprehend and dominate the recursive tools of this autopoietic discourse.

In each of the rewriting modules, the re-dos must be followed up by discussions on the applicability conditions. For the written text to look like a TG typical of the school mathematical discourse and, therefore, be an endorsed narrative indeed, such conditions must gradually incorporate details and increase students' perception about the subject being studied. Therefore, each of the modules will constitute a discourse learning phase for the students on the theme of the activity, in such a way that the discourse will be improved not only through what students occasionally know about triangles, for example, as they begin their studies, but also through each rewriting they produce.

Therefore, the teaching of mathematics - seen as a mathematical discourse that produces its own TG, the endorsed narratives, conditions to self-support this discourse eminently written - cannot marginalize the production of these narratives. The architecture herein proposed corroborates this opinion, since the student will be allowed to gradually reflect on the processes of constructing, substantiating and recalling narratives.

\section{Final considerations}

The understanding of mathematics as a discourse, adopted by Sfard (2008), relates to a type of communication set with certain allowable actions and how these determine certain types of reactions. The notion of discourse proposed by Marcuschi (2008) has to do with language uses; they are institutionalized achievements in spheres of socially-organized human activity. Through these theoretical lenses, Mathematics can be seen as a discourse or a discursive domain, which produces and organizes a set of activities through their own tools, the use of words and visual mediators, in routines that lead to the production of narratives considered TG.

In this sense, it can be realized that the production and incorporation of new objects into the mathematical discourse are achieved through the production and use of TG as in an autopoietic system: TG are discourse objects and allow access to them.

Thus, considering mathematics as a discourse led to the conclusion that the didactic sequence model proposed by Dolz, Noverraz and Schneuwly (2004) to the teaching of textual production is also a useful guideline for the teaching of mathematical discourse, leading to the proposition of a didactic sequence architecture that is specific for the teaching of school mathematical discourse according to the conception of mathematics as a product of human activity, that is, as a discourse. In line with Marcuschi's (2008) idea, this article considered that dominating texts is a way to master the language and to enter a culture. Thus, learning how to write endorsed narratives is a way to insert students in school culture, through the school mathematical discourse, for as they gradually incorporate production strategies of mathematical facts into their knowledge repertoire, they increasingly enter the structure of the school and literary mathematical discourse, becoming more able to solve more complex problems of various types, from day-to-day problems to those related to the academic environment. 
Teaching mathematics from the perspective ...

\section{Acknowledgments}

The author thanks the cooperation of the Programa de Apoio ao Recém-Doutor (PARD) of the Universidade Federal do Sul e Sudeste do Pará.

\section{References}

DOLZ, J.; NOVERRAZ, M.; SCHNEUWLY, B. Sequências didáticas para o oral e a escrita: apresentação de um procedimento. In: SCHNEUWLY, B.; DOLZ, J. (Org). Gêneros orais e escritos na escola. Campinas: Mercado de Letras, 2004. p. 95-128.

MARCUSCHI, L. Gêneros textuais: definição e funcionalidade. In: DIONISIO, A. P.; MACHADO, A. R.; BEZERRA, M. A. (Org.). Gêneros textuais e ensino. São Paulo: Parábola Editorial, 2010. p. 20-38.

Produção textual, análise de gêneros e compreensão. São Paulo: Parábola Editorial, 2008.

PIETROPAOLO, R. C. Proporcionalidade: uma idéia fundamental. In: MURRIE, Z. F. (Org.). Matemática: livro do estudante: ensino fundamental. 2. ed. Brasília: MEC: INEP, 2006. p. 127-148.

PIRES, C. M. C. A arte de raciocinar. In: MURRIE, Z. F. (Org.). Matemática: livro do estudante/ensino fundamental. Brasília: MEC/INEP, 2006. p. 31-56.

RIPARDO, R. B. Escrever bem aprendendo matemática: tecendo fios para uma aprendizagem matemática escolar. 2014. 314 f. Tese (Doutorado) - Faculdade de Educação, Universidade de São Paulo, São Paulo, 2014.

RODRIGUES, W. S. Os números: seus usos e seus significados. In: MURRIE, Z. F. (Org.). Matemática: livro do estudante: ensino fundamental. Brasília: MEC: INEP, 2006. p. 57-80.

ROGERI, N. K. O. Geometria: leitura e representação da realidade. In: MURRIE, Z. F. (Org.). Matemática: livro do estudante/ensino fundamental. Brasília: MEC: INEP, 2006. p. 81-102.

SFARD, A. Thinking as communicating: human development, the growth of discourses, and mathematzing. Cambridge: Cambridge University Press, 2008.

Artigo recebido em 22/08/2016. Aceito em 18/04/2017.

Universidade Federal do Sul e Sudeste do Pará (UNIFESSPA), Instituto de Ciências Exatas, Folha 17, Quadra 4, Lote Especial Nova Marabá, CEP 68500-290, Marabá, PA, Brasil. 
